\title{
Evaluation of diagnostic accuracy of serum calcium channel a $\delta 1$ subunit in hepatocellular carcinoma-related cirrhosis
}

\author{
Ahmed Elmetwally Ahmed, Essam Bayoumi, Ahmed E Khayyal, Al Saied Al Refaey and Hagar Elessawy* (D)
}

\begin{abstract}
Background: Hepatocellular carcinoma (HCC) is one of the commonest malignancies worldwide that carries a bad prognosis particularly in Egypt due to the high prevalence of HCV burden. Late diagnosis of HCC especially in cirrhosis suffering-liver is one of the causes that worsen HCC outcome. Identification of molecular pathways of HCC will open the gate for early diagnosis and effective management. Oscillation of calcium controlled by the a $2 \delta 1$ subunit has been proposed as one of the mechanisms in tumor-initiating cell properties of HCC. In this study, we aim to evaluate the serum a $2 \delta 1$ subunit level as a biological marker for HCC. A total of 90 participants were enrolled, 40 patients with HCC, 40 patients with cirrhosis, and 10 healthy volunteers; serum level of a2 $\delta 1$ was assessed in all participants with ELISA

Results: The mean serum levels of a2 $\delta 1$ were significantly higher in HCC group (19.53 $\pm 6.87 \mathrm{ng} / \mathrm{dL}$ ) than cirrhotic $(6.24 \pm 2.64 \mathrm{ng} / \mathrm{dL})$ and control groups $(0.67 \pm 0.48 \mathrm{ng} / \mathrm{dL})(P=0.001)$. There was no significance between $\mathrm{a} 2 \delta 1$ and etiology of liver disease as viral (HCV, HBV) or non-viral $(P=0.14)$.
\end{abstract}

Conclusion: a2 $\delta 1$ subunit may serve as a potential non-invasive marker with excellent sensitivity for diagnosis of HCC regardless of the etiology of liver disease.

Keywords: Hepatocellular carcinoma, a2 $\delta 1$ subunit, CSCs, HCV, HBV, Novel marker

\section{Background}

Liver malignancy is the sixth commonest malignancy worldwide with an incidence of approximately 841,000 new cases in 2018 [1], of which hepatocellular carcinoma (HCC) represents $80 \%$ [2], and considered the fourth leading cause of cancer-related death worldwide [3]. In Egypt, HCC is the fourth common cancer [4].

HCC has molecular subgroups reflecting the biological background and might have prognostic potential and selection criteria for therapy; among the subgroups there are two major subtypes each encompassing almost $50 \%$ of patients: one, proliferation class, which is poorly differentiated, had worse clinical outcome, expressing high alpha-fetoprotein (AFP) levels with more vascular

\footnotetext{
* Correspondence: hagarahmed@med.asu.edu.eg; doch_ain@hotmail.com Department of Internal Medicine, Gastroenterology and Hepatology Unit, Faculty of Medicine, Ain Shams University, Cairo 11566, Egypt
}

invasion, and commonly associated with HBV infection; the other class, non-proliferation, more commonly associated with alcohol-related HCC or HCV infection, had better outcome with moderate to well differentiation [5].

In 1994, Lapidot and his team introduced the concept of cancer stem cell (CSC) through transplantation of acute myeloid leukemia (AML) cells from recently diagnosed patients into severe combined immune deficient (SCID) mice [6]. This CSC can self-renew, differentiate into all tumor cell lines giving the criteria of tumor hierarchy and intra-tumoral heterogeneity, have the unique tumorinitiating capability, and own high resistance to chemotherapy [7]. They possess many names as CSCs, tumorinitiating cells (TICs), or cancer stem-like cells [8].

Many CSCs have been identified in HCC, one of them was isoform 5 of the cell surface voltage-gated calcium channel $\alpha 2 \delta 1$ described by Zhao et al. [9], they inject 
$\alpha 2 \delta 1+$ cells subcutaneously in (non-obese diabetic) NOD/SCID mice, there was higher tumorigenic potential in comparison with $\alpha 2 \delta 1-$ cells. Also, they showed that $\alpha 2 \delta 1$ regulates calcium signaling and intracellular calcium levels, which is vital for activating signaling cascades that regulate gene transcription and various cell functions; one of them is the phosphorylation of ERK $1 / 2$ which prevents cell apoptosis [9].

Calcium oscillations not only occur in excitable tissues spontaneously, such as muscle, SAN, and neuronal tissues [10], but also occur in pluripotent cells (embryonic stem cells), multipotent cells (mesenchymal stem cells), immature dendritic cells, and G0/G1-phase cells [11]. Zhao et al.'s study proposed that $\alpha 2 \delta 1$ was involved in amplitude-encoding signals that maintain the properties of HCC TICs and showed that inhibition of this calcium signaling could be a therapeutic strategy for HCC [9].

Other authors showed that there were other types of cancer that contain $\alpha 2 \delta 1+$ cells such as small-cell lung cancer, laryngeal squamous cell carcinoma, and gastric cancer, with nearly the same stem cell-like properties [12], resistant to chemotherapy [13], and overexpression of ERK1/2 [14]. Also, they showed that inhibition of $\alpha 2 \delta 1$ may serve as a new promising therapeutic target for these CSCs $[15,16]$.

The standard of care for surveillance of $\mathrm{HCC}$ is by ultrasound (US) with or without AFP every 6 (4-8) months in a cirrhotic patient [17] and the cornerstone in diagnosis is multiphasic CT and/or MRI. The problem of US is its low sensitivity (46\%) especially in detecting small lesions [18] dropping to $33 \%$ in obese patients with BMI $>30$ [19]; also, AFP had a sensitivity of around 60\% [17]. However, CT and MRI had higher sensitivity (69\% and $84 \%$, respectively) and specificity (94\%), yet not recommended to be used as surveillance tools $[17,20]$. That necessitates finding a new tool that can detect HCC early with high sensitivity and specificity non-invasively at low cost. From the aforementioned biological properties of $\alpha 2 \delta 1$ subunit in tumor-initiating cells in HCC, we assume that it may have also a good diagnostic value.

\section{Methods}

The present study was conducted at the Ain Shams University Hospitals, Cairo, in the duration between December 2018 and December 2019. A case-control study was designed with a total of 90 subjects enrolled and divided into 3 groups as follow: 40 patients with HCC, 40 patients with cirrhosis with normal AFP and no radiological evidence of $\mathrm{HCC}$, and 10 apparently healthy individuals as a control group, with no previous history of liver and other chronic disease or malignant diseases and negative for hepatitis viral markers. HCC patients were diagnosed according to definitive criteria in multiphasic CT/MRI showing arterial enhancement and delayed venous washout; any subject that had a history of malignancy of other organs, inflammatory diseases, or hematological diseases was excluded. The study protocol was approved by the local ethics committee of Ain Shams University. Informed consent was taken from both the patients and control group subjects after explaining the aim and concerns of the study. For all subjects, the following were done: a collection of relevant clinical data, basic laboratory tests including alanine aminotransferase (ALT), aspartate aminotransferase (AST), bilirubin, serum albumin, AFP, INR, CBC, kidney function test, and hepatitis serology (HBsAg and HCV $\mathrm{Ab})$ levels were measured using commercially available kits.

\section{Blood sample collection, storage, and analysis}

The serum sample was collected from all study subjects. Collected serum was allowed to clot for $10-20 \mathrm{~min}$ at room temperature. Centrifuge was at 2000-3000 rpm for $20 \mathrm{~min}$. When the analysis was not performed immediately, the samples were frozen and stored at $80^{\circ} \mathrm{C}$ until use. The serum concentration of the $\alpha 2 \delta 1$ subunit was measured using an ELISA kit according to the manufacturer's guidelines (MyBioSource, USA).

\section{Statistical analysis}

IBM SPSS Advanced Statistics version 21 (SPSS Inc., Chicago, IL, USA) was used for statistical analysis. The quantitative variables were presented as the mean \pm standard deviation or median percentile of the interquartile range (25th to 75th) for non-parametric data analysis done by the Mann-Whitney test. For parametric comparison between two/all study groups, Student $t$ test or ANOVA was used. Spearman rho was used for correlation. The receiver operating characteristic (ROC) curve was applied to identify the best cut-off values for, the $\alpha 2 \delta 1$ subunit. $P$ values of $<0.05$ were considered significant.

\section{Results}

\section{Baseline characteristics of the studied subjects}

The mean age of the whole studied sample was 50.5 years $( \pm 11.75)$ and the number distribution of gender among all subjects was $60(66.6 \%)$ male and 30 $(33.3 \%)$ female. The etiology of liver disease in the studied sample: 12 patients (15\%) were HBV positive, where 45 patients $(56.25 \%)$ were $\mathrm{HCV}$ positive, the remaining 23 patients $(28.75 \%)$ were non-viral causes of liver disease (Table 1). Liver fibrosis was assessed by FIB-4 with a median value of 3.01 (IQR 2.03) across both groups. The number of smokers across both HCC and cirrhotic groups was 26 (32.5\%); 54 $(67.5 \%)$ were non-smokers. Regarding associated 
Table 1 Socio-clinical criteria of the study population and relationship with a $2 \delta 1$

\begin{tabular}{|c|c|c|c|c|}
\hline & Cirrhosis $(N, 40)$ & $\operatorname{HCC}(N, 40)$ & Control $(N, 10)$ & Test \\
\hline Age, mean (SD) & $55.62( \pm 4.67)$ & $51( \pm 11.62)$ & $28.1( \pm 3.38)$ & $r=0.14^{*}, P=0.19$ \\
\hline \multicolumn{5}{|l|}{ Gender } \\
\hline Male (\%) & $29(72.5 \%)$ & $24(40 \%)$ & 7 (70\%) & $t=0.70$ \\
\hline Female (\%) & $11(27.5 \%)$ & $16(40 \%)$ & $3(30 \%)$ & $P=0.48$ \\
\hline \multicolumn{5}{|l|}{ FIB 4} \\
\hline Min-max & $1.48-6.33$ & $1.33-16$ & - & $r=-0.03^{*}$ \\
\hline Median (IQR) & $3.12(1.52)$ & $2.7(2.55)$ & - & $P=0.77$ \\
\hline HBV & $1(2.5 \%)$ & 11 (27.5\%) & - & \\
\hline $\mathrm{HCV}$ & $28(70 \%)$ & 17 (42.5\%) & - & $F=2.00^{* *}$ \\
\hline Non-viral & $11(27.5 \%)$ & $12(30 \%)$ & - & $P=0.14$ \\
\hline
\end{tabular}

*Spearman Rho

**ANOVA test

comorbidities in both groups, 16 patients $(20 \%)$ had hypertension and 29 (36.25\%) had diabetes (Table 3). Child-Pugh A in this studied sample was 3 patients (7.5\%) in the cirrhotic group and 12 patients (30\%) in the HCC group. Child-Pugh B was 36 patients (90\%) and 22 patients (55\%) in cirrhotic and HCC groups, respectively. Child-Pugh $\mathrm{C}$ in the cirrhotic group was 1 patient (2.5\%) while in the HCC group were 6 patients (15\%). The median value AFP in the cirrhotic group was $4.9 \mathrm{IU} / \mathrm{mL}$ (IQR 2.7) while its median value in $\mathrm{HCC}$ group was $485 \mathrm{IU} / \mathrm{mL}$ (IQR 463). The mean value of the MELD score in cirrhotic groups was $18.5 \pm 2.3$, while in the HCC group the mean value was $16.6 \pm 5.3$.

As regards radiological characteristics of HCC, considering size, 12 lesions (30\%) were $<3 \mathrm{~cm}, 21$ lesions (52.5\%) between 3 and $5 \mathrm{~cm}$, and 7 lesions (17.5\%) >5 $\mathrm{cm}$. Considering the number of lesions, 22 lesions were single (55\%) and $18(45 \%)$ were multiple; no infiltrative HCC pattern nor portal vein invasion were present in the study group.

There were statistically significant differences between the cirrhotic group and HCC group as regard ALT,

Table 2 Lab results in the study sample and relationship with a2 $\delta 1$

\begin{tabular}{|c|c|c|c|c|c|}
\hline & Cirrhosis $(N, 40)$ & $r^{*}, P$ value & $\operatorname{HCC}(N, 40)$ & ${ }^{*} r, P$ value & Mann-Whitney\#, $P$ value \\
\hline$\overline{A L T} I U / L$ & & 0.19 & & -0.19 & \\
\hline Min-max & $17-54$ & 0.23 & $8-90$ & 0.25 & $U=434.5$ \\
\hline Median (IQR) & $24(10)$ & & $49.5(38.25)$ & & $P<0.01$ \\
\hline AST IU/L & & 0.28 & & -0.25 & \\
\hline Min-max & $19-46$ & 0.08 & $10-118$ & 0.12 & $U=490$ \\
\hline Median (IQR) & $28.5(10.75)$ & & $44(33.5)$ & & $P<0.01$ \\
\hline T.BIL mg/dL & & 0.27 & & -0.05 & \\
\hline Min-max & $1.2-2.7$ & 0.09 & $0.4-9.1$ & 0.75 & $U=737.5$ \\
\hline Median (IQR) & $2.05(1.5)$ & & $2.1(2.28)$ & & $P=0.53$ \\
\hline Albumin $\mathrm{g} / \mathrm{dL}$ & & -0.02 & & 0.19 & \\
\hline Min-max & $1.7-3.9$ & 0.89 & $2-4.9$ & 0.24 & $U=347$ \\
\hline Median (IQR) & $2.75(0.7)$ & & $3(0.28)$ & & $P<0.01$ \\
\hline INR & & 0.29 & & -0.01 & \\
\hline Min-max & $1.4-2.3$ & 0.07 & $1.1-2.8$ & 0.94 & $U=515$ \\
\hline Median (IQR) & $1.89(0.18)$ & & $1.7(0.6)$ & & $P<0.01$ \\
\hline Platelet $10^{3} / \mathrm{mL}$ & & -0.31 & & -0.01 & \\
\hline Min-max & $56-156$ & 0.05 & $45-198$ & 0.94 & $U=795$ \\
\hline Median (IQR) & $100(39)$ & & $99(42.75)$ & & $P=0.962$ \\
\hline
\end{tabular}

*Spearman Rho test between lab and $a 2 \delta 1$

${ }^{\#}$ Comparison between cirrhosis and $\mathrm{HCC}$ as regards labs 
AST, serum albumin, and INR, while there were no statistically significant differences between the two groups as regard total bilirubin and platelet (Table 2).

\section{a2 $\delta 1$ subunit levels among studied subjects}

The serum levels of $\alpha 2 \delta 1$ subunit were significantly different across all 3 groups $(F=99.65, P<0.001)$ with the highest value in HCC group (mean $=19.53 \pm 6.87 \mathrm{ng}$ / $\mathrm{dL}, 95 \% \mathrm{CI}$ 17.33-21.72), then the cirrhotic group (mean $=6.24 \pm 2.64 \mathrm{ng} / \mathrm{dL}, 95 \% \mathrm{CI} 5.39-7.09)$ and the least value in control group (mean $=0.67 \pm 0.48 \mathrm{ng} / \mathrm{dL}, 95 \%$ CI 0.32-1.02). Also, post hoc LSD test showed significant difference between control group and both the cirrhotic and HCC groups $(P=0.002$ and 0.001, respectively) and between the HCC and cirrhotic groups $(P=0.001)$.

\section{Evaluation of serum a $2 \delta 1$ subunit in-clinic- laboratory feature and etiology of liver disease}

The mean levels of $\alpha 2 \delta 1$ in males were $11.04 \pm 8.45 \mathrm{ng} /$ $\mathrm{dL}$ while in females were $12.51 \pm 9.67 \mathrm{ng} / \mathrm{dL}$; this showed no statistically significant differences across all study subjects. Also, there was no correlation with age or FIB-4 (Table 1). The mean value of $\alpha 2 \delta 1$ in HCV patients was $11.57 \pm 8.96 \mathrm{ng} / \mathrm{dL}$ and in HBV patients was $16.93 \pm 6.04 \mathrm{ng} / \mathrm{dL}$, while in the non-viral group was $13.35 \pm 8.09 \mathrm{ng} / \mathrm{dL}$; this was nonsignificant (Table 1 ). There were no statistically significant differences between the mean levels of $\alpha 2 \delta 1$ as regarding smoking status, diabetes, and hypertension within each group (cirrhotic and HCC) (Table 3). AFP in both the HCC and cirrhotic groups showed strong positive correlation with $\alpha 2 \delta 1$ ( $r=0.85, P<0.001)$. However, there was no statistically significant difference between the $\alpha 2 \delta 1$ subunit as regards laboratory tests (ALT, AST, total bilirubin, albumin, and INR) within each group (Table 2). Despite platelets showing significant correlation in the cirrhotic group, this correlation was a very weak negative correlation $(r=-0.31, P=0.05)$.
Evaluation of serum $a 2 \delta 1$ subunit as a potential diagnostic marker for HCC

To further investigate the diagnostic value of serum $\alpha 2 \delta 1$ subunit in HCC, ROC curves were constructed revealed excellent diagnostic value with $\mathrm{AUC}=0.974$ and $P<0.0001$. The serum level of the $\alpha 2 \delta 1$ subunit at the cut-off value $\geq 8.75 \mathrm{ng} / \mathrm{dL}$ showed a sensitivity of $95 \%$, a specificity of $80 \%$, a positive predictive value (PPV) of $82.6 \%$, and a negative predictive value (NPV) of $94.1 \%$ with accuracy $=87.5 \%$. However, its level at a cut-off 12 $\mathrm{ng} / \mathrm{dL}$ showed a sensitivity of $85 \%$, a specificity of $100 \%$, PPV of $100 \%$, and NPV of $87 \%$ with accuracy $=92.5 \%$

\section{Discussion}

Many studies showed an expression of $\alpha 2 \delta 1$ subunit in different types of malignancies such as pancreatic [21], ovarian [22], and lung tumors [14] and demonstrated a potential resistance to chemotherapy and may carry bad prognosis. Han et al. as well identified a subpopulation of TICs expressing $\alpha 2 \delta 1$ subunit, which is essential for the activation of calcium influx that controls the TIC ability of HCC by an antibody against Hep-12 cells [23] Since the liver cancer is one of the highest malignancies in Egypt and carries a bad prognosis, early diagnosis and management are essential [24].

In the present study, the serum level of $\alpha 2 \delta 1$ subunit was significantly higher in the HCC group than both the cirrhotic and control group, in agreement with the study conducted by Zhao et al. who first reported $\alpha 2 \delta 1$ subunit in HCC; on 86 freeze resected HCC tumor sample compared to the nearby para-cancerous area for the presence of 1B50-1 positive staining (a monoclonal $\mathrm{Ab}$ against $\alpha 2 \delta 1$ subunit), they a found significantly higher percent in tumor cells (72.1\%) than non-tumor cells (46.5\%), $P=0.0006$ [9].

The study conducted by Badr et al. was in agreement with our results as they showed significantly higher levels of serum $\alpha 2 \delta 1$ subunit in HCC group than both the cirrhotic and control $(P<0.05)$ with mean values as

Table 3 Comorbidity distribution among the main two groups and level of a $2 \delta 1$

\begin{tabular}{|c|c|c|c|c|c|c|c|c|}
\hline & \multicolumn{4}{|l|}{ Cirrhosis } & \multicolumn{4}{|l|}{$\mathrm{HCC}$} \\
\hline & $N, 40$ & Mean (SD) & $t$ & $P$ & $N, 40$ & Mean (SD) & $t$ & $P$ \\
\hline \multicolumn{9}{|l|}{ Smoking } \\
\hline Yes, N (\%) & $15(37.5)$ & 6.88 (3.03) & -1.12 & 0.27 & $11(27.5)$ & $16.66(7.31)$ & -1.57 & 0.13 \\
\hline No, N (\%) & $25(62.5)$ & $5.86(2.37)$ & & & $29(72.5)$ & $20.61(6.50)$ & & \\
\hline \multicolumn{9}{|l|}{ Diabetes } \\
\hline Yes, N (\%) & $6(15)$ & $7.00(2.92)$ & -0.75 & 0.46 & $23(57.5)$ & $20.74(6.39)$ & -1.31 & 0.20 \\
\hline No, N (\%) & $34(85)$ & $6.11(2.62)$ & & & $17(42.5)$ & $17.89(7.36)$ & & \\
\hline \multicolumn{9}{|l|}{ Hypertension } \\
\hline Yes, N (\%) & $1(2.5)$ & 5 & 0.47 & 0.64 & $15(37.5)$ & $19.51(7.35)$ & 0.02 & 0.99 \\
\hline No, N (\%) & $39(97.5)$ & $6.28(2.68)$ & & & $25(62.5)$ & $19.54(6.73)$ & & \\
\hline
\end{tabular}


$20.12 \pm 3.7 \mathrm{ng} / \mathrm{mL}, 10.41 \pm 3.4 \mathrm{ng} / \mathrm{mL}$, and $10.2 \pm 2.98$ $\mathrm{ng} / \mathrm{mL}$, respectively. However, they did not find a significant difference between the cirrhosis and control groups and this was against our finding as we found significantly lower levels in the control than cirrhosis $(P=$ $0.002)$; this may be attributed by the sample size used in their study [25].

In work-related to Zhao et al.'s study, Han and his team performed the expression level of $\alpha 2 \delta 1 \mathrm{mRNA}$ in 85 of the resected HCC and para-cancerous area found that there were no significant differences between its level and clinicopathological features (age, gender, and cirrhotic vs non-cirrhotic) [23]; this was as our findings.

Serum $\alpha 2 \delta 1$ subunit level was not significantly different in associated comorbidity as smoking, DM, and HTN or viral (HBV and HCV) or non-viral etiology of liver disease.

Badr et al. who first describe serum level of $\alpha 2 \delta 1$ subunit as a potential marker for HCC found that the sensitivity and specificity at level $14.22 \mathrm{ng} / \mathrm{dL}$ are $100 \%$ and 96\%, respectively, with PPV 98\%, NPV 100\%, and accuracy $98.7 \%$ [25]. Per that, we found a sensitivity of $95 \%$ and specificity of $80 \%$ at a level of $\geq 8.75 \mathrm{ng} / \mathrm{dL}$ with PPV of $82.6 \%$, NPV of $94.1 \%$, and accuracy of $87.5 \%$; this indicates that serum level of $\alpha 2 \delta 1$ subunit may be used as a good biomarker for diagnosis of $\mathrm{HCC}$ with high sensitivity regardless of the different etiologies of liver disease as shown in our results. Besides, we demonstrated a higher level that yields more specificity and higher diagnostic potentially of $\alpha 2 \delta 1$ subunit was that at a cut-off of $12 \mathrm{ng} / \mathrm{dL}$; sensitivity and specificity were $85 \%$ and $100 \%$, respectively, with $100 \%$ PPV, $87 \%$ NPP, and $92.5 \%$ accuracy.

Some authors found that the $\alpha 2 \delta 1$ subunit may have a role in prognosis and recurrence of HCC. Zhao and his team showed that the presence of positive staining of anti $\alpha 2 \delta 1$ subunit antibodies cells in the para-cancerous tissues did correlate significantly with hepatic very rapid recurrence, and a lower rate of 4-year overall survival post-surgery $(P=0.00004$ and 0.00005 , respectively). Also, Han et al. identified that high level of $\alpha 2 \delta 1 \mathrm{mRNA}$ is an independent risk factor of poor survival for HCC patients (relative risk $=2.66, P=0.005)[9,23]$

\section{Conclusion}

The study showed serum $\alpha 2 \delta 1$ subunit as a potential non-invasive marker with excellent sensitivity for diagnosis of HCC regardless of the etiology of liver disease and not affected by common comorbidity as smoking, diabetes, and hypertension.

\section{Abbreviations}

AFP: Alfa fetoprotein; ALT: Alanine aminotransferase; AML: Acute myeloid leukemia; ANOVA: Analysis of variance; AST: Aspartate aminotransferase; AUC: Area under the curve; CSCs: Cancer stem cells; CT: Computed tomography; DM: Diabetes; ELISA: Enzyme-linked immunosorbent assay; ERK: Extracellular signal-regulated kinases; FIB-4: Fibrosis index based on four factors; HBV: Hepatitis B virus; HCC: Hepatocellular carcinoma; HCV: Hepatitis C virus; HTN: Hypertension; INR: International normalized ratio;

IQR: Interquartile range; LSD: Least significant difference; MELD: Model for End-Stage Liver Disease; MRI: Magnetic resonant image; mRNA: Messenger RNA; NOD: Non-obese diabetic; NPP: Negative predictive value; PPV: Positive predictive value; ROC: Receiver operating characteristic; SAN: Sinoatrial node; SCID: Severe combined immune deficiency; TICs: Tumor-initiating cells;

US: Ultrasonography

\section{Acknowledgements}

The authors thank all the staff members of the radiology, clinical pathology, and internal medicine (gastroenterology and hepatology unit) departments at Ain Shams University Hospital, Cairo, Egypt.

\section{Authors' contributions}

All authors read and approved the final manuscript. AA had selected the idea and had made the final revision of data. EE did the data gathering. HE did data analysis and manuscript preparation. EB and AK did study design and revision of the manuscript. The authors read and approved the final manuscript.

\section{Funding}

This research did not receive any specific grant from funding agencies in the public, commercial, or not-for-profit sectors.

\section{Availability of data and materials}

The datasets used and/or analyzed during the current study are available from the corresponding author on reasonable request.

\section{Ethics approval and consent to participate}

All individual included in the study signed an informed written consent to participate. All procedures performed in this study were in accordance with the standards of the Ethical Research Committee of Ain Shams University (reference number not applicable).

\section{Consent for publication}

Not applicable

\section{Competing interests}

None

Received: 13 May 2020 Accepted: 20 August 2020

Published online: 01 September 2020

\section{References}

1. Bray F, Ferlay J, Soerjomataram I, Siegel RL, Torre LA, Jemal A (2018) Global cancer statistics 2018: GLOBOCAN estimates of incidence and mortality worldwide for 36 cancers in 185 countries. CA Cancer J Clin 68(6):394-424

2. Zhu RX, Seto W-K, Lai C-L, Yuen M-F (2016) Epidemiology of hepatocellular carcinoma in the Asia-Pacific region. Gut and liver 10(3):332

3. Wang H, Naghavi M, Allen C, Barber RM, Bhutta ZA, Carter A, Casey DC, Charlson FJ, Chen AZ, Coates MM (2016) Global, regional, and national life expectancy, all-cause mortality, and cause-specific mortality for 249 causes of death, 1980-2015: a systematic analysis for the Global Burden of Disease Study 2015. Lancet 388(10053):1459-1544

4. Rashed WM, Kandeil MAM, Mahmoud MO, Ezzat S (2020) Hepatocellular carcinoma (HCC) in Egypt: a comprehensive overview. J Egypt Natl Canc Inst 32(1):5

5. Llovet JM, Montal R, Sia D, Finn RS (2018) Molecular therapies and precision medicine for hepatocellular carcinoma. Nat Rev Clin Oncol 15(10):599-616

6. Lapidot T, Sirard C, Vormoor J, Murdoch B, Hoang T, Caceres-Cortes J, Minden M, Paterson B, Caligiuri MA, Dick JE (1994) A cell initiating human acute myeloid leukaemia after transplantation into SCID mice. Nature 367(6464):645-648

7. Batlle E, Clevers H (2017) Cancer stem cells revisited. Nat Med 23(10):11241134

8. Clarke M, Dick J, Dirks P, Eaves C, Jamieson C, Jones D, Visvader J, Weissman I, Wahl G (2006) Cancer stem cells-perspectives on current status and future 
directions: AACR Workshop on cancer stem cells. Cancer Res 66(19):93399344

9. Zhao W, Wang L, Han H, Jin K, Lin N, Guo T, Chen Y, Cheng H, Lu F, Fang W (2013) 1B50-1, a mAb raised against recurrent tumor cells, targets liver tumor-initiating cells by binding to the calcium channel a $2 \delta 1$ subunit. Cancer Cell 23(4):541-556

10. Ferreira-Martins JO, Rondon-Clavo C, Tugal D, Korn JA, Rizzi R, Padin-Iruegas ME, Ottolenghi S, De Angelis A, Urbanek K, Ide-Iwata N (2009) Spontaneous calcium oscillations regulate human cardiac progenitor cell growth. Circ Res 105(8):764-774

11. Kapur N, Mignery GA, Banach K (2007) Cell cycle-dependent calcium oscillations in mouse embryonic stem cells. Am J Phys Cell Phys 292(4): C1510-C1518

12. Zhang Z, Zhao W, Lin X, Gao J, Zhang Z, Shen L (2019) Voltage-dependent calcium channel a2 $\delta 1$ subunit is a specific candidate marker for identifying gastric cancer stem cells. Cancer Manag Res 11:4707

13. Huang C, Li Y, Zhao W, Zhang A, Lu C, Wang Z, Liu L (2019) a2 $\delta 1$ may be a potential marker for cancer stem cell in laryngeal squamous cell carcinoma. Cancer Biomark 24(1):97-107

14. Yu J, Wang S, Zhao W, Duan J, Wang Z, Chen H, Tian Y, Wang D, Zhao J, An Tet al (2018) Mechanistic exploration of cancer stem cell marker voltagedependent calcium channel a $2 \delta 1$ subunit-mediated chemotherapy resistance in small-cell lung cancer. Clin Cancer Res 24(9):2148-2158

15. Sainz B Jr, Heeschen C (2013) Standing out from the crowd: cancer stem cells in hepatocellular carcinoma. Cancer Cell 23(4):431-433

16. Schulte L-A, López-Gil JC, Sainz B, Hermann PC (2020) The cancer stem cell in hepatocellular carcinoma. Cancers (Basel) 12(3):684

17. Marrero JA, Kulik LM, Sirlin CB, Zhu AX, Finn RS, Abecassis MM, Roberts LR, Heimbach JK (2018) Diagnosis, staging, and management of hepatocellular carcinoma: 2018 practice guidance by the American Association for the Study of Liver Diseases. Hepatology 68(2):723-750

18. Nam CY, Chaudhari V, Raman SS, Lassman C, Tong MJ, Busuttil RW, Lu DS (2011) CT and MRI improve detection of hepatocellular carcinoma, compared with ultrasound alone, in patients with cirrhosis. Clin Gastroenterol Hepatol 9(2):161-167

19. Esfeh JM, Hajifathalian K, Ansari-Gilani K (2020) Sensitivity of ultrasound in detecting hepatocellular carcinoma in obese patients compared to explant pathology as the gold standard. Clinical and molecular hepatology 26(1):54

20. Roberts LR, Sirlin CB, Zaiem F, Almasri J, Prokop LJ, Heimbach JK, Murad MH, Mohammed K (2018) Imaging for the diagnosis of hepatocellular carcinoma: a systematic review and meta-analysis. Hepatology 67(1):401-421

21. Davies A, Kadurin I, Alvarez-Laviada A, Douglas L, Nieto-Rostro M, Bauer CS, Pratt WS, Dolphin AC (2010) The a $2 \delta$ subunits of voltage-gated calcium channels form GPI-anchored proteins, a posttranslational modification essential for function. Proc Natl Acad Sci U S A 107(4):1654-1659

22. Yu D, Holm R, Goscinski MA, Trope CG, Nesland JM, Suo Z (2016) Prognostic and clinicopathological significance of Cacna2d1 expression in epithelial ovarian cancers: a retrospective study. Am J Cancer Res 6(9):2088-2097

23. Han H, Du Y, Zhao W, Li S, Chen D, Zhang J, Liu J, Suo Z, Bian X, Xing B (2015) PBX3 is targeted by multiple miRNAs and is essential for liver tumour-initiating cells. Nat Commun 6(1):1-16

24. Gawish EA, Abu-Raia GY, Osheba I, Sabry A, Allam E (2020) Association between miR-196a2 polymorphism and the development of hepatocellular carcinoma in the Egyptian population. Egyptian Liver Journal 10(1):1-10

25. Badr SA, Fahmi MW, Nomir MM, El-Shishtawy MM (2018) Calcium channel a2 $\delta 1$ subunit as a novel biomarker for diagnosis of hepatocellular carcinoma. Cancer biology \& medicine 15(1):52

\section{Publisher's Note}

Springer Nature remains neutral with regard to jurisdictional claims in published maps and institutional affiliations.

\section{Submit your manuscript to a SpringerOpen ${ }^{\circ}$ journal and benefit from:}

- Convenient online submission

- Rigorous peer review

- Open access: articles freely available online

- High visibility within the field

Retaining the copyright to your article

Submit your next manuscript at $\boldsymbol{\nabla}$ springeropen.com 